\title{
Filosofia política moçambicana: por um novo projeto de democracia
}

\author{
Mozambican political philosophy: for a new democracy project
}

\author{
Lorena Silva Oliveira*
}

Resumo: O presente artigo visa apresentar como o filósofo Severino Ngoenha coloca a filosofia moçambicana a serviço da reflexão sobre sua temporalidade e contexto histórico, tendo em vista pensar o processo democrático de Moçambique e apresentar os fundamentos necessários para uma dimensão moçambicana da democracia. Nesta perspectiva, este trabalho amparado em suas obras Os Tempos da Filosofia: filosofia $e$ democracia moçambicana e Filosofia Africana: das independências às liberdades apresenta, através de um triplo contratualismo, os fundamentos propostos pelo filósofo para que Moçambique conquiste um modelo institucional de democracia. Em tom conclusivo, consideramos que a filosofia africana pode ser compreendida como um instrumento fundamental na construção de um projeto de futuro melhor para o continente africano, como para Moçambique, pois ela pode fornecer alternativas para que os povos africanos caminhem rumo à liberdade.

Palavras-chave: Filosofia Africana; Política; Democracia

Abstract: This article aims to present how the philosopher Severino Ngoenha puts Mozambican philosophy at the service of reflection on its temporality and historical context, with a view to thinking about Mozambique 's democratic process and presenting the necessary foundations for a Mozambican dimension of Democracy. In this perspective, this work, based on his works The Times of Philosophy: mozambican philosophy and democracy and African Philosophy: From Independence to Freedoms presents, through a triple contractualism, the foundations proposed by the philosopher so that Mozambique conquer an institutional model of democracy. In conclusion, we consider that African philosophy can be understood as a fundamental instrument in the construction of a better future project for the African continent, as for Mozambique, since it can provide other alternatives for African peoples to move towards freedom.

Keywords: African Philosophy; Politics; Democracy

Pensar filosoficamente o processo democrático de Moçambique é o objetivo do filósofo Severino Ngoenha em sua obra Os Tempos da Filosofia: filosofia e democracia moçambicana ${ }^{1}$. Contudo, é preciso ressaltar que o filósofo discorre sobre a situação política de Moçambique em outros trabalhos que produziu, como seu célebre livro Filosofia Africana: das independências às liberdades² publicado em 1993.

\footnotetext{
* Doutoranda em Filosofia-PPGF/UfRJ. Co-coordenadora do Núcleo de Filosofia Política Africana-GERU MÃ̃/UFRJ. Pesquisadora Associada ao Núcleo de Estudos Afro-brasileiros-NEAB/UFU. E-mail: professoralorenaoliveira@gmail.com

${ }^{1}$ NGOENHA, Os tempos da filosofia: filosofia e democracia moçambicana, 2004.

${ }^{2}$ NGOENHA, Filosofia africana: das independências às liberdades, 1993
} 
Nesta obra, Ngoenha além de tecer suas críticas à etnofilosofia, defende que o compromisso da filosofia africana é com o futuro. Por este fato, também discorre sobre a situação política de Moçambique, tendo como base as experiências e erros da I República Moçambicana, para demonstrar aos intelectuais a necessidade destes se preocuparem com o futuro político do país, para que a sociedade não corra o risco de reviver os erros do passado.

Como é notório a preocupação do filósofo com o futuro, este, diante do cenário político de Moçambique na II República, com a consciência do seu papel enquanto um intelectual, na obra "Os Tempos da Filosofia", analisa como ocorreu o processo de implementação da democracia em seu país, sem deixar de tecer suas considerações sobre esta forma de governo, haja vista que, para este filósofo "Cada época, cada geração define um objetivo que aos seus olhos constitui a sua própria contribuição para a história dos homens"3.

Portanto, a postura e a análise do filósofo, em suas obras, podem ser compreendidas, como a sua contribuição para implementação de uma democracia que seja condizente com a realidade e a história dos africanos/moçambicanos.

Dito isto, a democracia na filosofia ngoenhiana é uma questão filosófica imprescindível! Através do voto, cada indivíduo escolhe o modo de sociedade que anseia. Logo, há um problema de caráter existencial no processo eleitoral, pois os indivíduos não escolhem simplesmente um modelo político, mas "o tipo de futuro que queremos que seja o nosso e por consequência, dos nossos filhos, sem condicionamentos ideológicos” 4 . Portanto, o autor assegura que:

O problema da democracia não é redutível a uma simples questão de eleições de partidos ou de presidentes, mas implica antes de mais, e sobretudo, o lugar que o povo tem que ocupar nas decisões dos problemas fundamentais que lhe dizem respeito, e nos mecanismos jurídicos, para que tenha um controlo real sobre a realidade política, econômica, social e educativa ${ }^{5}$.

Nesta perspectiva, a democracia está para além de um processo eleitoral. Ela está totalmente relacionada à efetivação das liberdades individuais e dos grupos, de participarem das decisões públicas, por ser uma forma de governo que tem como fundamento o governo de acordo com as decisões do povo, da maioria. Ela "consiste na inserção de cada indivíduo no seio da comunidade, e na participação integral de sua vida.

\footnotetext{
${ }^{3}$ Ibidem, p. 7.

${ }^{4}$ Ibidem, p. 10.

${ }^{5}$ NGOENHA, Os tempos da filosofia: filosofia e democracia moçambicana, p. 9.
} 
Cada indivíduo deve poder cooperar, ouvir e fazer sentir a sua opinião, ajudar e fazer-se ajudar, amar e ser amado" ${ }^{.}$

Significa que nós, indivíduos, somos os comandantes de nossa sociedade. Por este fato, não precisamos exatamente utilizarmos conceitos abstratos para compreendermos nem para a explicarmos, pois, a democracia refere-se à constituição de um espaço político, que na ótica ngoenhiana, só pode ser cunhado através das diferentes concepções culturais, políticas e sociais dos povos de uma dada sociedade.

Tal concepção não quer dizer que o filósofo tenha excluído a dimensão axiológica que a democracia assenta. Os valores da democracia: o respeito pelos direitos do homem, a igualdade entre os cidadãos e o respeito pela dignidade das pessoas, possuem, para o autor, caráter universal e não negociáveis.

A questão de fundo da sua concepção está relacionada à dimensão institucional da democracia. Esta, não possui caráter unívoco. A história das instituições nos mostra que elas emergiram de contextos históricos, sociais e culturais específicos, o que justifica as diferenças entre os modelos institucionais da democracia nos diversos países do mundo.

Por este ângulo, o filósofo acredita que a constituição de modelos institucionais de democracia, devem ser aculturados à realidade histórica e cultural de cada sociedade, pois tão somente a instituição poderá se legitimar. É do substrato cultural, dos aspectos característicos de uma realidade específica, ao qual o sistema irá operar, que se deve formular o modelo institucional que conseguirá corresponder politicamente às concepções de mundo dos diferentes povos constituintes de uma nação.

Consequentemente, modelos institucionais específicos de outros países não podem serem transpostos a outras sociedades, pois o contrário acarretaria, no que o filósofo conceitua como genocídio cultural da dimensão política. Sendo assim, Ngoenha tece uma crítica às sociedades que possuem experiência democráticas a mais tempo que os países africanos e tentam impor modelos institucionais. Para ele, estas sociedades "[...] podem partilhar conosco as suas experiências, mas não podem servir de modelo porque as modalidades da racionalidade ocidental são historicamente situadas e não susceptíveis de ser levianamente transferidas para outras latitudes"7.

Além da crítica, o filósofo pondera que "A filosofia política tem a função de explicar as regras da democracia e a definição da organização do político, quando o regime é ameaçado do interior ou do exterior, e de salvá-la contra quem a coloca em perigo" ${ }^{\text {. Cabe }}$ a ela, opor-se às ameaças internas que queiram reduzir a política ao campo dos interesses individuais e/ou partidários. Ela "deve reafirmar o primado do político sobre o econômico, da deliberação popular sobre os índices das bolsas de valor”..

\footnotetext{
${ }^{6}$ NGOENHA, Filosofia africana: das independências às liberdades, p. 159.

${ }^{7}$ NGOENHA, Os tempos da filosofia: filosofia e democracia moçambicana, p. 93.

${ }^{8}$ Ibidem.

${ }^{9}$ Ibidem.
} 
Logo, Ngoenha é um filósofo político democrata, que preserva todos os princípios da democracia e está engajado em convocar a Filosofia Política Moçambicana a contribuir para o pensar filosófico sobre a democracia, tendo em vista a maximização das liberdades democráticas dos indivíduos e povos moçambicanos.

Consequentemente, as reflexões que adentraremos visam ponderar, de acordo com Ngoenha, se a política e seus modelos institucionais de democracia, impostos pelo ocidente, ampliam ou não os campos da liberdade dos africanos. Analisemos.

\section{Os constrangimentos para uma democracia moçambicana}

Em 1994, com a proclamação de uma Nação Democrática em Moçambique, após o fim da guerra civil, a nação passou a reconhecer os sujeitos como partícipes da vida da sociedade e do Estado, proclamando em sua constituição que "Todos se reconhecem actores e sujeitos da história, ou seja, um partido único não pode ser o dirigente da sociedade e do Estado"10. Fato que altera a forma como os cidadãos, anteriormente, compreendiam e se relacionavam com o governo.

Assim, a legislatura da II República instaurou o sistema democrático em Moçambique construindo no país um parlamento representativo, partidos políticos, meios de comunicação de massas privados como: televisão, jornais, rádios, instituições de ensino secundário e superior. Ocorreram novas formações políticas, organizações civis e sociais, crescimento econômico e sobretudo, liberdade de opinião.

No entanto, na II República, dois elementos, na perspectiva ngoenhiana, constrangem o nascimento de uma real democracia moçambicana. $O$ primeiro elemento diz respeito ao modelo de democracia que foi condicionada a Moçambique e o segundo elemento, refere-se ao direito de representatividade dos povos.

O governo da II República foi um governo caracterizado pela imposição política da comunidade internacional que mantém sob tutela a economia e a política moçambicana. Logo, a democracia instaurada em Moçambique é uma democracia liberal que possui valores, leis e lógica produtivista dos países ocidentais.

Este fato, leva Ngoenha a conceituar o Estado da II República como dólar-crático, uma vez que, para o filósofo, neste governo tudo se fez em função do dólar. As elites políticas, os funcionários públicos utilizam o serviço público a favor dos seus próprios interesses econômicos. A corrupção invadiu a mentalidade dos servidores do Estado, e estes utilizam os valores ocidentais de democracia como um instrumento para realização de interesses econômicos próprios, em detrimento dos interesses da população.

A dólar-cracia tornou o Estado ausente da vida pública, colocou a economia onde a paz tinha lugar e tal ausência resultou em uma extrema desigualdade entre ricos e pobres,

\footnotetext{
${ }^{10}$ Ibidem, p. 116.
} 
aumentando progressivamente a violência social. Neste contexto, Ngoenha afirma que a lógica produtivista, que fundamenta o Estado dólar-crático, precedeu os valores propriamente políticos da democracia.

O princípio da justiça, que regulamenta a vida social, no campo econômico e do direito foi negligenciado em função da dólar-cracia, que se tornou o fim que justifica todos os meios. Estes fatos, leva-nos a perceber que, apesar da II República buscar instaurar um sistema democrático em Moçambique, com a criação de um parlamento, partidos, dentre outros elementos constituintes de uma sociedade democrática, a

[...] segunda República muito depressa oscilou da democracia a "dólarcracia”. Com a passagem da primeira República à segunda república, deitou-se fora a água suja e o bebé. Valores verdadeiros para qualquer cidadão foram negligenciados, deliberadamente omitidos ou mesmos invertidos ${ }^{11}$.

Se partirmos da concepção ngoenhiana de democracia, compreenderemos que ocorre no cenário político de Moçambique, como de alguns países africanos, a instauração de modelos institucionais da democracia que não corresponde às características sociais, culturais, muito menos política da nação o qual opera. A nação democrática moçambicana, possui na sua gênese, os valores dos vencedores da guerra, que em troca de auxílio financeiro determinam a forma como Moçambique deve gerir sua economia e consequentemente sua política.

Deste modo, Ngoenha conclui que há em Moçambique um “democratismo (que é diferente da democracia), super liberalismo que se traduz em privatizações sumárias, tutela governativa [...]"12, pois a dimensão econômica e social da vida coletiva impõe-se em detrimento do projeto político, enfraquecendo o Estado Moçambicano e o impossibilitando de cumprir o seu papel enquanto um Estado democrático, por necessitar cumprir as imposições antidemocráticas do FMI e do Banco Mundial.

Junta-se a isto que, em 1994, a II República ao implementar os sistemas de partido, que por sua vez é tipicamente ocidental, não avaliou se este sistema é capaz de representar os diferentes povos desta sociedade. No entanto, percebe-se que muitos países africanos demonstraram não conseguirem, através desta modalidade, mobilizar o imaginário coletivo das populações. Sendo assim, o filósofo põe-se a analisar que:

Das duas uma: ou o africano (e, portanto, também o moçambicano) é geneticamente anti-democrático como sustentam alguns eugenistas (Medeved Arison), ou então o sistema de partidos, é talvez neste momento,

\footnotetext{
${ }^{11}$ Ibidem, p. 102.

${ }^{12}$ Ibidem, p. 126.
} 
um mal necessário, mas não corresponde ao substrato cultural dos nossos $\operatorname{povos}^{13}$.

Do ponto de vista ngoenhiano, os africanos não são de forma alguma antidemocráticos, e nos reportando à sua concepção de democracia, podemos afirmar que os sistemas de partidos ocidentais também são inadequados e não coaduna com as culturas africanas. Não representa a heterogeneidade cultural dos povos.

Isto, leva-nos a questionarmos, portanto, como a heterogeneidade dos povos que constituem Moçambique, podem serem representados em um sistema que possui valores discrepantes, estabelece uma única língua como oficial do país e obedece a leis externas, que são do ponto de vista interior, antidemocráticas? Haveria outros veículos de opinião, outras formas destes cidadãos sentirem-se representados e reivindicarem contra este sistema político discrepante com a sua sociedade?

Apesar do Estado Moçambicano de 1994 instaurar um sistema democrático no país, este não criou mecanismos jurídicos legais que possibilitem os cidadãos fazerem-se ouvidos e participarem efetivamente da vida pública de Moçambique. A criação de parlamentos, portanto, estaria a representar somente os interesses dos partidos e não os das populações.

Por fim, é evidente que Moçambique não possui uma real democracia, visto que os povos não possuem nem instrumentos que efetivem sua participação na sociedade, sendo a participação na vida pública a maior característica desta modalidade de governo, segundo os seus fundamentos. Como também, o modelo institucional dólar-crático é discrepante com a realidade social e cultural destes povos, indo de encontro ao que Ngoenha compreende por democracia.

Por respeito à democracia, o filósofo considera que os africanos devem "tomar a sério a especificidade cultural que nós somos e representamos e inventar um modelo institucional que se inspire nos substratos culturais das populações” ${ }^{14}$, pois na sua ótica, o que há em Moçambique é um jogo de interesses políticos que prejudica a constituição de uma democracia que proclame a justiça social e que seja realmente benéfica para os povos.

O filósofo, vislumbra a urgência da construção de modelos institucionais que sejam genuinamente africanos e que possua legitimidade política nos povos autóctones, como também os permitam participar com efeito nas decisões públicas. A vista disso, acreditamos que um dos problemas centrais da obra Os Tempos da Filosofia: filosofia $e$ democracia moçambicana reside em investigar,

[...] como fazer com que a democracia não se transforme num jogo de elites, que a maioria da população possa, de facto, participar com conhecimento de causa, não só através de um boletim de voto de cinco em cinco anos,

\footnotetext{
${ }^{13}$ Ibidem, p. 116.

${ }^{14}$ Ibidem, p. 86.
} 
como uma assinatura de cheque em branco para as elites políticas que se sentem legitimadas a fazer privatizações que vão em detrimento do povo que nelas depositou confiança? ${ }^{15}$

Esta questão orienta as reflexões de Ngoenha, contudo, ressalto que além dos motivos outrora citados que constrangem o nascimento de uma democracia moçambicana, o filósofo salienta que os moçambicanos ainda são incapazes de assumir a responsabilidade que a liberdade comporta, ou seja, os moçambicanos ainda não possuem instrumentos que orientem e possibilitem a formação de espaços de liberdade, instituições de formação e reivindicações políticas, devido ao histórico político que não os permitiram desenvolverem uma cultura de participação efetiva na vida pública.

A I República deu aos moçambicanos a concepção sobre o que é um Estado que promove a justiça social, mas não os permitiam participar das decisões nem expressarem livremente suas opiniões sobre os rumos da vida social e política. Enquanto a II República, deu aos moçambicanos a noção de liberdade para a participação na vida pública, porém os condenaram a um sistema econômico que os mesmos não tinham formação e informação para adentrarem, como também os negaram juridicamente, mecanismos para uma real participação na vida integral da sociedade.

Neste ínterim, Ngoenha sustenta que Moçambique necessita de instrumentos que oriente sua política a promover concomitantemente a justiça social e a liberdade de expressão como também os permitam conseguir assumir a responsabilidade que a liberdade/soberania requer para desempenhar as prerrogativas de um Estado soberano e democrático.

Enquanto um intelectual que busca exercer sua função social, ao analisar filosoficamente a realidade política de Moçambique, os erros e acertos que ocorreram durante as duas repúblicas, apresenta-nos sua contribuição para o desenvolvimento econômico e social de seu país e, consequentemente, para a construção de um novo projeto de democracia.

Acredita, ser necessário o estabelecimento de um projeto de sociedade que estabeleça um triplo contrato moçambicano, que deve ser composto por um contrato cultural, um contrato social e um contrato político, para que uma democracia moçambicana possa emergir sem condicionamentos políticos, ideológicos e econômicos advindos do exterior.

Com o triplo contratualismo, o filósofo aspira moçambicanizar as instituições democráticas do país, por acreditar que com a instauração destes contratos, o modelo institucional de democracia será moçambicano, vez que irá emergir da história, da cultura e do substrato político nacional construído a partir dos princípios que as forças sociais e políticas de Moçambique cunharam.

\footnotetext{
${ }^{15}$ Ibidem, p. 98
} 
Assim, apresento a seguir, os contratos que podemos considerar ser, na filosofia de Ngoenha, os fundamentos para que Moçambique consiga conquistar a liberdade almejada, a saber: o desenvolvimento econômico e social e construir uma democracia moçambicana. Todavia, dado os limites deste trabalho, apresentarei apenas as principais características e propostas de cada contrato.

\section{O contrato cultural}

Para discorrer sobre o contrato cultural, precisamos ter em mente que alguns intelectuais africanos, dentre eles filósofos e economistas, discutem na história do pensamento africano, sobre as possíveis relações entre Modernidade e Tradição. Na tradição filosófica, parte deste debate, interroga-se, sobretudo, quanto a capacidade democrática das tradições africanas que, por não fomentarem o debate de ideias, consequentemente tornam-se um entrave para o desenvolvimento democrático do país.

Os conhecimentos tradicionais e suas relações com o mundo moderno são questionados por grande parte da tradição filosófica africana, chegando a dividi-la em duas posições contrastantes: filósofos como Towa, Elungu, Ébénézer Njoh Mouelle, consideram que há uma irredutibilidade fundamental entre os conhecimentos tradicionais e a racionalidade moderna. Para estes filósofos, a África deve ter a ousadia de sacrificar suas tradições em nome do desenvolvimento.

Em contrapartida, a tradição africana é vista como compatível com o desenvolvimento moderno, pelo fato de ter sido esta que permitiu a sobrevivência de África, à escravatura e ao colonialismo. Sua vitalidade cultural, segundo os pensadores W.E. Abraham, Tshipanga, Matala, dentre outros, que a fez sobreviver. O não desenvolvimento do continente, deve-se à elite política que manipulou as culturas visando solidificar suas posições de poder.

No entanto, independentemente das diferentes lucubrações levantadas, sobre a possibilidade da tradição e modernidade coexistirem, em Moçambique é fato que tradição e modernidade sempre andaram juntas. A saber, de acordo com Ngoenha, a sociedade moçambicana possui diferentes etnias e cada uma possui um sistema jurídico próprio em relação ao direito do Estado.

Há no país, uma cultura jurídica caracterizada pelo fenômeno da duplicidade jurídica. O que significa que, apesar de Moçambique possuir uma estrutura jurídica elaborada pelos jurisconsultos de Lisboa, desde o período colonial, há uma estrutura jurídica e política local das tradições que nunca conseguiu ser destruída.

Mesmo após a colonização e independência, operava nas instituições do governo os modelos jurídicos do ocidente, e ainda assim, o pluralismo jurídico continuou a existir. Moçambique, desta forma, estabeleceu durante toda sua história uma coexistência jurídica 
e este fato é de suma importância para compreendermos a importância do contrato cultural proposto pelo filósofo moçambicano.

Entretanto, antes de apresentar o contrato cultural, relevo que a tradição é um fator notável na sociedade Moçambicana e que, por este fato, Ngoenha inspirado em Eboussi Boulaga e preocupado com o futuro, afirma-nos que a tradição em todas as gerações deve ser encarada como uma utopia crítica. Em sua obra Filosofia Africana: das Independências às liberdades, o filósofo apresenta-nos sua compreensão:

Falar da tradição como utopia crítica significa, portanto, o bom uso da tradição. Isto é possível através duma memória vigilante, que não ataca cegamente a tradição. Falar da tradição como utopia crítica significa combater uma tradição que leva à morte e à alienação do "Muntu". A tradição não é um corpo fechado, mas aberto. Neste sentido não é inimiga da modernidade, não se opõe à modernidade; ela pode ser transportada no projecto da modernidade e, portanto, da autenticidade africana. Neste projeto torna-se modelo de cultura, de unidade, no esforço de construção de um modelo comum de "Muntu". Ela não está simplesmente na origem, mas está também a fim de oferecer modelos utópicos para o agir actual ${ }^{16}$.

A partir desta citação e das obras de Ngoenha, compreendo que para a filosofia ngoenhiana, devemos rever o passado e apreender das culturas tradicionais unicamente os elementos que as mesmas oferecem para resolução dos problemas atuais e futuros. Castiano nos explica que no pensamento do autor "A condição de olhar para trás é, pois, quando essas lucubrações filosóficas, estão intrinsicamente ligadas a melhoria da vida das populações africanas em função de projectos sociais" ${ }^{17}$.

O filósofo, portanto, adverte que tendo em vista o presente, a escolha dos elementos que a tradição nos oferece, deve visar a melhoria da realidade social de Moçambique. Por sua vez, a realidade é democrática, logo, se há no passado elementos que contribui, positivamente, na construção do elã de democratização dos países africanos, estes elementos devem ser bem-vindos.

Após essa breve digressão sobre a tradição na filosofia de Ngoenha, pode-se entender que a coexistência jurídica existente em Moçambique, durante toda sua a história, ratifica o engajamento de Ngoenha em buscar desenvolver um contrato cultural em seu país, visto que, o fato de a coexistência jurídica perdurar, demonstra-nos que, de fato, Moçambique nunca possuiu uma constitucionalidade que correspondesse ao imaginário coletivo dos povos; como por outro lado, demonstra-nos que as condições para a presença das culturas na legitimação política já existem e que,

\footnotetext{
${ }^{16}$ NGOENHA, Filosofia africana: das independências às liberdades, p. 100.

${ }^{17}$ CASTIANO, Referenciais da filosofia africana: em busca da intersubjetivação, p. 201.
} 
[...] um novo direito mais democrático e mais integrador sob o ponto de vista do desenvolvimento é possível. Porém, ele tem de ter muito mais em conta as diferentes mentalidades moçambicanas e será nestas condições mais eficaz que os planos de desenvolvimento até aqui muito decalcados dos modelos ocidentais ${ }^{18}$.

Diante deste terreno oportuno, para que o modelo institucional da democracia consiga possuir uma dimensão moçambicana, o autor propõe à Moçambique um contrato cultural, que significa "apreender o essencial do espírito da tradição e, ao mesmo tempo, acolher a modernidade de uma maneira também critica e seletiva” ${ }^{19}$.

Ou seja, o filósofo propõe em seu contrato cultural que os modelos institucionais da democracia procedam dos imaginários coletivos, das linguagens, do modo como os povos de Moçambique concebem a vida social e coletiva. Vale destacar que, pelo fato de o contrato cultural buscar o essencial da tradição para constituição de um modelo institucional moçambicano, não significa que ele vise excluir a dimensão axiológica da democracia, que por sua vez é inegociável.

O contrato cultural não objetiva restituir os valores tradicionais, nem seguir os dogmas da tradição. O autor, ao propor este contrato cultural, visa possibilitar a compreensão de que,

[...] se a dimensão axiológica da democracia se manteve a mesma em todos os países ditos ocidentais, a forma institucional variou de lugar para lugar, de Nação para Nação. Cada país pensou na democracia axiológica inventando, digo bem criando, parturindo instituições sociais adequadas a esta nova maneira de socialização, a partir da compreensão dos imaginários coletivos das suas populações, a partir da própria história ${ }^{20}$.

$\mathrm{Na}$ visão do filósofo, Moçambique precisa criar um projeto de sociedade que tenha como referência as diferentes culturas. Um projeto de sociedade, sério e duradouro, inspirado nos substratos culturais das populações, que consiga dar a Moçambique uma estabilidade política. No entanto, isto se dará quando os moçambicanos enfrentarem e estudarem desde o interior sua própria história e sua própria cultura.

Quando se inspirarem na tradição, sublimá-la e através do processo de metástase, conseguirão criar um direito que corresponda às diferentes concepções de vida política e social que as populações conservam. O domínio sobre a realidade cultural é visto por Ngoenha como condição necessária para que os moçambicanos sejam fautores do seu futuro, pois a falta de conhecimento e o descaso com a cultura e a história, por sua vez,

\footnotetext{
${ }^{18}$ NGOENHA, Os tempos da filosofia: filosofia e democracia moçambicana, p. 184.

${ }^{19}$ Ibidem, p.165.

${ }^{20}$ Ibidem, p. 162.
} 
possibilita os mesmos serem vítimas, novamente, da própria história. Ou seja, serem neocolonizados e eternamente tutelados pelos órgãos internacionais.

Portanto, os moçambicanos devem conhecerem profundamente a si mesmos, ou seja, devem refletirem sobre o que de fato eles são e o que é Moçambique, sua sociedade e cultura. Quais são os seus desejos e aspirações. Devem fazer um inquérito, traçar os objetivos, os ideais, as utopias e, a partir deste inquérito, pensarem o direito para enfim constituírem uma democracia moçambicana.

Os intelectuais moçambicanos, neste empreendimento, contêm um papel primordial, pois por um lado, os mesmos possuem a capacidade de se apoiarem "na cultura e, por outro, de suscitar o interesse das culturas pelas atividades que, à primeira vista, não têm nada a ver nem com o espírito, nem com os interesses dos grupos” ${ }^{21}$. Desta forma, os intelectuais (porta-vozes da comunidade) conseguem estabelecer um diálogo entre o campo cultural e político.

O filósofo certifica que, se os intelectuais não empreenderem neste projeto, as pessoas desinteressarão das atividades públicas, colocando em perigo a democracia e o desenvolvimento econômico do país. Entretanto, cabe nos questionar: como se consolidará este contrato?

O contrato cultural dar-se-á prioritariamente entre o Estado e os subgrupos sociais, estabelecendo as obrigações morais que ambos possuirão sobre suas ações na sociedade. $\mathrm{O}$ filósofo acredita que a diversidade cultural não impede a criação de uma dimensão moçambicana da democracia, por compreender que uma nação depende da capacidade do projeto político harmonizar as divergências entre os grupos, segundo regras que são legítimas para todos.

Por isso, considera que um novo projeto político para Moçambique deve conseguir unir e reconhecer as etnias que constituem a sociedade de forma digna e igualitária. Por fim, o contrato cultural requer a criação de espaços institucionais que fomentem o diálogo contínuo e sistemático, como também o diálogo de reconciliação entre a sociedade, os intelectuais e o Estado. Estes espaços servirão para a implementação democrática, pois devemos lembrar que democracia para o filósofo "consiste na inserção de cada indivíduo no seio da comunidade e na participação integral na vida daquela" ${ }^{22}$.

\section{Contrato social}

Se o substrato do pensamento filosófico africano sempre foi a busca pela liberdade, no contrato social de Ngoenha, o paradigma libertário acrescentará a busca pela justiça social. Buscando contribuir na construção de uma dimensão moçambicana da democracia,

\footnotetext{
${ }^{21}$ Ibidem, p. 170

${ }^{22}$ Ibidem, p. 187.
} 
o filósofo analisa que no Estado dólar-crático moçambicano “ o substrato da vida política não obedece a nenhum princípio ético; as leis não secundam a procura da justiça” ${ }^{23}$ e o sentimento de injustiça invadem os cidadãos como a violência torna-se o reflexo da extrema desigualdade entre ricos e pobres.

Contudo, Ngoenha acredita que uma sociedade democrática deve buscar, através do princípio da justiça social, impedir o aumento das desigualdades sociais e materiais entre os indivíduos e não condicionar os mesmos a um grau extremo de desigualdades. Por este fato, o autor vislumbra a necessidade de se estabelecer um contrato social que, para além da busca pela liberdade/soberania, também busque implantar a justiça em Moçambique.

$\mathrm{Na}$ esteira de John Rawls que interpreta justiça como equidade, Ngoenha convoca seu conceito de contrato para metê-lo ao serviço da justiça, pois considera que sem a mesma não é possível haver liberdade. A essência do princípio da justiça, para este filosofo, é a possibilidade de esta tornar possível a relação social e a vida dos indivíduos em sociedade.

É ela que torna possível a política fazer um trabalho de caráter ético sem prescindir uma redistribuição equitativa na sociedade. Tanto que, o autor considera a imagem da costureira o melhor símbolo para representar a justiça no contexto africano, composto por uma heterogeneidade cultural e social que precisa ser unida e não dividida. Semelhante a uma costureira, que utiliza linhas dispersas e diferentes e cose-as, tendo como objetivo unir e fazer um todo, sem rasgar o tecido, podemos compreender a importância do princípio da justiça social em uma sociedade democrática.

Portanto, o autor acredita que Moçambique precisa acrescentar à liberdade democrática a preocupação que encontramos já em Rousseau. É preciso que a democracia funcione em prol da diminuição das desigualdades entre pobres e ricos, em prol da justiça distributiva. A liberdade, advinda da democracia liberal, por si só não garante uma democracia de fato, pois não é possível ser livre em uma organização que propicie a desigualdade social.

À vista disso, seu contrato social tem como pauta equiponderar liberdade e justiça social, e considera caber à filosofia moçambicana, fundamentar a liberdade e a justiça, servir de substrato mental, filosófico e cultural na análise sobre as questões políticas nacionais, desenvolver espaços de liberdade, transformar as situações de injustiça, elaborar propostas e esclarecimentos políticos, tendo como fim transformá-los e fomentar debates que visam a transformação política em função de um futuro verdadeiramente democrático em Moçambique.

\section{Contrato político}

${ }^{23}$ Ibidem, p. 147 
No decorrer da obra Os Tempos da Filosofia: filosofia e democracia moçambicana percebemos, distintamente, que lutar contra o colonialismo, libertar Moçambique e ser soberano são os principais conceitos que constituem a nação moçambicana. Ulteriormente, a democracia, como a independência tornaram-se valores moçambicanos também a preservar, mas ainda é necessário buscar fomentar formas de participação e restituição do poder ao povo.

No contrato político, Ngoenha busca instruir as forças políticas e sociais moçambicanas para que estas consigam assegurar a democracia e a soberania em Moçambique. A história política do país nos mostra que, após a independência, o país possuía uma república unipartidária e após a guerra civil, na segunda república, instaurouse o sistema democrático no país dando a oportunidade de mais partidos pleitearem o governo moçambicano.

Todavia, o governo sob o comando da Frente de Libertação Nacional, segundo o filósofo, e com a interferência da Comunidade Internacional, faz a vontade dos doadores FMI e BM- a fim de ter investimentos, mas, concomitantemente, isola politicamente a Renamo ${ }^{24}$ e os outros partidos da oposição.

No entanto, este isolamento diminui a possibilidade de uma verdadeira democracia, como também, o centralismo político tende a impedir a possibilidade da construção de uma cultura política moçambicana, isto é, a criação de um substrato político nacional a partir de valores dos homens moçambicanos.

Rememorando os principais conflitos do país, como a escravatura, o colonialismo, o neocolonialismo e a guerra civil, Ngoenha afirma que todos estes eventos, foram facilitados, muitas vezes, pelas divisões internas como pela marginalização da oposição no debate político nacional. Em contrapartida, o contrato político entre a Udenamo ${ }^{25}, \mathrm{Manu}^{26}$ e Unamo ${ }^{27}$, evidencia que quando os africanos se uniram, foram fortes e conseguiram resistir.

Diante disso, preconiza que para um futuro democrático e soberano do país, os partidos políticos não podem serem isolados e não devem se encararem como inimigos. Por conseguinte, as forças políticas de Moçambique apesar de não possuírem um consenso, não falarem em uma só voz, precisam estabelecer uma interlocução entre elas, para que as mesmas, independentemente do partido político, defendam Moçambique; e ao

\footnotetext{
${ }^{24}$ Resistência Nacional Moçambicana é um partido político de Moçambique.

25 União Democrática Nacional de Moçambique foi um movimento formal de resistência à dominação portuguesa de Moçambique.

${ }^{26}$ Mozambique African National Union (União Nacional Africana de Moçambique) foi um dos movimentos de libertação de Moçambique.

${ }^{27}$ União Nacional Africana de Moçambique Independente (UNAMI) foi uma organização criada em 1961, que juntamente a MANU e UDENAMO dão origem à FRELIMO em 1962.
} 
negociarem com as instituições internacionais, falem com uma só voz, possuam e defendam os mesmos valores, que por sua vez, serão os valores da nação.

As forças sociais e os partidos devem se considerarem adversários, mas guardarem entre eles os anseios da nação. Devem disputarem apenas projetos políticos que incrementem as liberdades nacionais, a participação da população nos debates e nos espaços democráticos. Para mais, não devem rivalizar por questões étnicas e por apoios internacionais.

Devem, por fim, se unificarem para que Moçambique triunfe. Neste sentido, a interlocução entre as diferentes forças políticas é uma forma de salvaguardar, com prudência, os interesses dos moçambicanos, evitando que os estrangeiros tenham acesso aos anseios da nação e se sintam autorizados a quererem intervir em suas decisões.

A vista disso, para o filósofo, as forças sociais e políticas do país devem estabelecer um contratualismo moçambicano. Isto é, um contrato político que estabeleça os princípios, os valores materiais e imateriais, inalienáveis e imprescritíveis, que todo país possui e que simboliza sua liberdade, autonomia e soberania. Mas, que além de tudo todos os governantes devam respeitar e defender. Ngoenha enfatiza que

É indispensável criar um espaço público e uma espécie de contratualismo moçambicano. Para isso, deve-se concretizar um múnus de princípios, um contrato político que os governantes, independentemente da família política a que pertençam, deverão imperativamente respeitar e defender a todo custo, um número de valores mesmo materiais, que não podem ser alienados sem o consentimento explícito dos moçambicanos, através de um referendo, por exemplo ${ }^{28}$.

Amparada no contexto moçambicano, analiso que a essência deste contrato é o estabelecimento de princípios que deverão nortear todos os governantes que Moçambique vier a ter. Mas, para a sua consolidação, é indispensável que haja realmente uma interlocução interna entre as forças políticas e sociais, para que a vida política moçambicana consiga prosperar e para que esse múnus de princípios consiga ser erigido.

Assim, como para a efetivação do contrato político, é extremamente necessário que as forças políticas moçambicanas juntamente com a sociedade estabeleçam o que é público e celebrem qual é "[...] a essência mesma da liberdade moçambicana, sobre o que não é negociável, o que deveria constituir o fundamento normativo do Estado" ${ }^{29}$, para que este, enfim, decrete o que constitui o patrimônio nacional e não é acessível a estrangeiros, a ONGs e cooperações.

Isto impossibilitará que haja, futuramente, privatizações de patrimônios simbólicos e materiais dos moçambicanos, como houve no Estado dólar-crático, devido a necessidade

\footnotetext{
${ }^{28}$ NGOENHA, Os tempos da filosofia: filosofia e democracia moçambicana, p. 214.

${ }^{29}$ Ibidem, p. 215.
} 
de pagamento das dívidas colossais, geradas pelos empréstimos dos organismos internacionais.

Podemos compreender que, as prerrogativas acima citadas, são alguns elementos suleadores para a construção de um novo contrato político em Moçambique. Acreditamos que o autor, ao sugerir a criação de um múnus de princípios visava moralizar a vida política do país, para que o futuro e a convivência civil em Moçambique, possua valores inalienáveis que conduza à efetivação da dimensão democrática moçambicana, do crescimento social e político como da liberdade/soberania, que os moçambicanos almejam. Ademais, o contrato político

Trata-se da necessidade de um renovar da vida política moçambicana, cultural (mais de participação dos diferentes componentes culturais na vida política) e deontologicamente- no relacionamento dos partidos políticos entre eles, mais de respeito das elites governativas pelos interesses do presente e do futuro de Moçambique, mais diálogo e mais escuta da vontade e dos interesses do povo ${ }^{30}$.

Compreendo que, com o contrato político, Ngoenha almeja uma transformação intelectual e moral no cenário político dos moçambicanos. Almeja a criação de espaços de liberdade na esfera pública para a participação efetiva dos grupos sociais na vida integral da sociedade, como também almeja um projeto de futuro para Moçambique que seja construído e mantido pelo diálogo entre os partidos e as forças sociais que representam a diversidade cultural do país.

A filosofia política africana, como um projeto do futuro, deve contribuir neste processo de transformação. Para o filósofo, cabe a ela, criar mecanismos de fomento da soberania na luta contra a intervenção da comunidade internacional, estimular a criatividade dos moçambicanos, libertando suas habilidades, a fim destes trabalharem em prol de assumir as responsabilidades da liberdade.

Mas além de tudo isto, a tarefa da filosofia africana para a execução destes contratos, é descobrir e inventar espaços de liberdades concretos, amparar os políticos nacionais com instrumentos e materiais teóricos "interrogar as legitimidades edificadas pelos homens (nacionais e internacionais) e tentar dar palavra as pessoas, grupos e culturas que foram privadas dela até aqui” ${ }^{31}$.

\section{Considerações finais}

A partir da concepção ngoenhiana de filosofia africana como projeto do futuro, percebe-se a importância dessa filosofia na luta pela liberdade compreendida como

\footnotetext{
${ }^{30}$ Ibidem, p. 216.

${ }^{31}$ Ibidem, p. 217.
} 
desenvolvimento social e econômico, soberania e democracia, não só em Moçambique, mas em todos os países africanos.

Por assim ser, a filosofia de Ngoenha, aqui apresentada, vem ofertar, através do triplo contratualismo, os fundamentos para que Moçambique conquiste uma democracia moçambicana. O filósofo, através do seu aporte, demonstra às filosofias que a "filosofia não se pode contentar em justificar o statu quo, mas ao contrário, deve dessacralizar os equilíbrios políticos que parecem únicos” ${ }^{32}$.

Nesta esteira, a filosofia africana tem o desafio de se debruçar sobre sua temporalidade e contexto histórico e buscar relevar, construir e fundamentar um projeto de futuro que estabeleça os princípios de um governo que realmente respeite a heterogeneidade dos povos africanos. Mas, verifica-se na análise que, o maior desafio das filosofias africanas, em especial em sua dimensão política, para que os países africanos conquistem a liberdade/soberania, não está em somente conseguir fundamentar ou inventar um modelo institucional próprio.

Percebe-se que, seu maior desafio, está em concentrar suas investigações nos conflitos entre as soberanias (Europa e Moçambique), refletindo e identificando quais são as dificuldades dos africanos em assumir plenamente sua soberania e quais mecanismos elaborar para que o Ocidente os liberte dos seus élans coloniais.

Por fim, através da análise das obras Os Tempos da Filosofia: filosofia e democracia moçambicana e Filosofia Africana: das independências às liberdades, considero que a Filosofia Política Africana é tida como um instrumento que instruirá o processo de construção de um futuro melhor no continente africano, como em Moçambique, pois a ela cabe criar os mecanismos de fomento da soberania, na luta contra a intervenção da comunidade internacional e estimular a criatividade dos moçambicanos, libertando suas habilidades, a fim destes trabalharem em prol de assumirem as responsabilidades que a liberdade comporta, construindo, assim, outras formas de interpretar e agir sobre sua própria história.

Ademais, estas obras filosóficas são fontes excelentes para introduzir os estudos sobre Filosofia Política Africana, nas modalidades de ensino público e privado de nosso país, visto que as mesmas retratam outras formas filosófico-políticas de buscar dar respostas à perpétua questão sobre: qual é o melhor regime político que satisfaça as exigências da justiça, ao evidenciar a importância de se considerar as diferentes concepções de mundo e organizações sociais no processo de qualquer deliberação/instauração de regimes políticos, econômicos, dentre outros.

\section{Referências}

\footnotetext{
${ }^{32}$ Ibidem.
} 
BRASIL. Plano nacional de implementação das diretrizes curriculares nacionais para a educação das relações étnico-raciais e para o ensino de história e cultura afro-brasileira e africana. Brasília, DF: MEC, SECADI, 2013, 104 p.

CASTIANO, J.P. Referenciais da filosofia africana: em busca da intersubjetivação. Maputo: Ndijra, 2010.

NGOENHA, S.E. Os tempos da filosofia: filosofia e democracia moçambicana. Maputo: Imprensa Universitária, 2004, 221p.

NGOENHA, S.E. Filosofia africana: das independências às liberdades. Maputo: Edições Paulistas, 1993, 183p. 